\title{
Managing ecosystems for service innovation: A dynamic capability view
}

\author{
Heiner Lütjen ${ }^{\mathrm{a}}$, Carsten Schultz ${ }^{\mathrm{b}, *}$, Frank Tietze ${ }^{\mathrm{c}}$, Florian Urmetzer ${ }^{\mathrm{c}}$ \\ ${ }^{a}$ VDI Technologiezentrum GmbH, 40468 Düsseldorf Germany \\ ${ }^{\mathrm{b}}$ Kiel University, Institute for Innovation Research, Westring 425, 24118 Kiel, Germany \\ ${ }^{\mathrm{c}}$ University of Cambridge, Institute for Manufacturing, Department of Engineering, Alan Reece Building, 7 Charles Babbage Road, Cambridge CB3 OFS, United Kingdom
}

\section{A R T I C L E I N F O}

\section{Keywords:}

Service innovation

Dynamic capability

Ecosystem

Open innovation

Servitization

Energy utilities

\begin{abstract}
A B S T R A C T
The success of service innovations is intertwined with firms' capabilities to coordinate, orchestrate, and collaborate with a set of external actors. Adopting an ecosystem and dynamic capability perspective, this article examines ecosystem-related capabilities for developing service innovation in product-centric firms. The research uses a mixed-methods approach focusing on the energy utility sector: (1) a survey with 133 managers from 28 firms that allows a comparison of ecosystem-related capabilities between firms with high and low service-innovation intensity; and (2) a complementary interview study with 8 of these firms that have high serviceinnovation intensity, allowing a detailed understanding of the relevant ecosystem-related capabilities to be developed.

From the data we derive a set of 12 ecosystem-related capabilities for service innovation related to the sensing, seizing, and reconfiguring of external resources. The results indicate that firms with high service-innovation intensity possess significantly stronger ecosystem-related capabilities than firms with lower serviceinnovation intensity. Those firms also seem to sense and seize external opportunities and resources to a greater extent in order to reconfigure their service-related ecosystems. The findings also show that successful service innovators consider not only value-adding partnerships, such as suppliers and customers, to be relevant for service innovation, but also relationships with non-direct value-adding ecosystem stakeholders (e.g., local governments, communities, legislators).
\end{abstract}

\section{Introduction}

In order to deliver service innovations, manufacturing and other product-centric firms are increasingly undergoing substantial organizational and resource transformations. These firms are shifting their businesses to services instead of, or in addition to, products - a trend referred to as servitization (Baines, Lightfoot, Benedettini, \& Kay, 2009; Gebauer, Fischer, \& Fleisch, 2010; Kowalkowski, Gebauer, Kamp, \& Parry, 2017; Lightfoot, Baines, \& Smart, 2013; Lütjen, Tietze, \& Schultz, 2017). Although several studies empirically support the idea that shifting to services positively affects firm success (e.g., Fang, Palmatier, \& Steenkamp, 2008), research has shown that service innovations are more challenging as a result of their fuzziness and riskiness compared to product innovations (Benedettini, Swink, \& Neely, 2017; Nijssen, Hillebrand, Vermeulen, \& Kemp, 2006; Schultz, Globocnik, Kock, \& Salomo, 2018; Storey \& Cankurtaran, 2016). A major issue concerns the "service paradox", when investments and higher costs in services do not lead to the expected returns, and firms struggle to generate profits from their service activities (Gebauer, Fleisch, \& Friedli, 2005; Kowalkowski,
Gebauer, Kamp, \& Parry, 2017; Neely, 2008). Combining a dynamic capability with an ecosystem perceptive, this study aims to investigate which ecosystem-related capabilities firms need in order to become successful service innovators, with a focus on actors outside their own firm.

Service innovations require firms' customers and other service ecosystem partners to be more deeply involved (Baines \& Lightfoot, 2013; Story, Raddats, Burton, Zolkiewski, \& Baines, 2017), which requires firms to be able to orchestrate their service ecosystem (Kindström, Kowalkowski, \& Sandberg, 2013; Martinez, Neely, Velu, Leinster-Evans, \& Bisessar, 2017). For example, in the empirical field we are focusing on energy utilities that commonly offer highly commoditized products, such as gas and energy, with limited space for product innovation. Nowadays, these firms are attempting to develop innovative services, such as smart e-mobility solutions. To do so, they need to build relationships with charging infrastructure suppliers, payment services, vehicle fleet managers, and grid-integration firms, but also other actors such as legislators, communities, and standardsetting bodies. In this respect, a firm's capability to build relationships

\footnotetext{
* Corresponding author.

E-mail addresses: luetjen@vdi.de (H. Lütjen), schultz@bwl.uni-kiel.de (C. Schultz), frank.tietze@eng.cam.ac.uk (F. Tietze), ftu20@cam.ac.uk (F. Urmetzer).
} 
with its entire business ecosystem becomes critical for service innovation (Eloranta \& Turunen, 2015; Opresnik \& Taisch, 2015; Kohtamäki and Rajala, 2016; Martinez et al., 2017).

Inarguably, scholars have already identified important capabilities to successfully manage external relationships for service innovation, with a specific focus on dynamic capabilities (Fischer, Gebauer, Gregory, Ren, \& Fleisch, 2010; Kindström et al., 2013; Teece, 2007). However, previous studies have barely considered the capabilities needed to cope with a diverse set of ecosystem actors, which are not always directly connected to the focal firm through value-adding relationships (e.g., government, regulatory institutions, local communities) (Frow, McColl-Kennedy, \& Payne, 2016; Akaka, Vargo, \& Lusch, 2013; Mele et al., 2015; Vargo and Lusch, 2011). Kohtamäki and Rajala (2016) conclude that a stronger focus on a "systemic, networked or ecosystem-like perspective" is valuable for understanding the prerequisites of service success (p. 3). Addressing this gap, this study intends to identify the specific ecosystem-related capabilities that firms require to become successful service innovators. As such, we build our study on the theoretical foundations of dynamic capabilities in business ecosystems. We consider both the specific requirements of service innovation, such as the intangibility and individuality of the co-creation process (Den Hertog et al., 2010), and the challenges that stem from relationships with value-adding and non-direct value-adding actors in a firm's ecosystem (Ford \& Gadde, 2003; Akaka et al., 2013; Mele et al., 2015).

The contribution of our study is fourfold: first, the results contribute to the literature by offering a more fine-grained view of service innovation in the context of business ecosystems. Kindström et al. (2013) and Fischer et al. (2010) were among the first to link dynamic capabilities to service innovation, and they offered a useful guide for the dynamic capabilities that firms must develop to become service innovators. More recently, scholars revealed that managers need to influence the capability development of their peers in the business network for developing new services (Töytäri et al., 2018). Furthermore, Huikkolla and Kohtamäki (2017) found that the ability to exploit the supplier ecosystem was a bottleneck for many service providers, but also a success factor to increase the number of innovations. This article extends the findings from these studies by adopting an ecosystem perspective for identifying specific ecosystem-related capabilities. Accordingly, this work responds to the call for more research on capabilities to orchestrate ecosystems for innovation (Helfat \& CampoRembado, 2015; Jacobides, Cennamo, \& Gawer, 2018).

Second, although service-innovation research has already examined the dyadic value-adding relationships of focal firms (Frow et al., 2016; Kohtamäki \& Partanen, 2016; Sjödin, Parida, \& Wincent, 2016), prior research has barely considered the specific capabilities needed to integrate stakeholders that are often not part of direct business-to-business relationships (Akaka et al., 2013; Frow et al., 2016). By adopting an ecosystem perspective, this article adopts a broad conceptualization and examines the capabilities necessary to integrate both value-adding and non-direct value-adding stakeholders.

Third, responding to the call for an improved measurement of service strategies (Kohtamäki, Partanen, Parida, \& Wincent, 2013), we provide a novel measurement of the underlying construct of the degree of service-innovation intensity. We argue that this service-innovation perspective can facilitate a better assessment of the phenomena of servitization by considering the number of service offerings and the service innovativeness.

Fourth, by providing insights obtained from the barely explored empirical field of energy utilities, this work responds to the call for extending the servitization discourse to commodity industries where it is difficult to maintain competitive product differentiation (Kowalkowski, Gebauer, \& Oliva, 2017).

To analyze dynamic capabilities for managing ecosystems for service innovation, we adopt a mixed-methods approach. While a quantitative survey study provides insights into the existing capabilities within firms, a qualitative empirical design reveals deeper insights into the nature of these capabilities. Hence, we combine two empirical approaches: (i) the quantitative multiple respondent survey data of 133 managers from 28 firms was used to compare firms with high and low service-innovation intensities. Thereby, we develop a finer-grained measurement of the underlying construct of the degree of service-innovation intensity, which may also be used in future research. In the second part, the qualitative interview study, we focus on eight firms with high service-innovation intensity in order to concentrate on the ecosystem-related dynamic capabilities that are necessary to deliver service innovation.

\section{Conceptual background}

\subsection{Service innovation and ecosystem literature}

The transformation whereby many firms are moving their business to services is accompanied by a substantial shift from the development of internal capabilities toward service-oriented relational capabilities that focus on the understanding of, and relationships with, actors in their ecosystem (Baines \& Lightfoot, 2013; Kindström \& Kowalkowski, 2014; Paiola, Saccani, Perona, \& Gebauer, 2013; Story et al., 2017). Research has shown that service innovation differs considerably from product innovation. Compared to product innovation, service innovation is more challenging as a result of its complexity and fuzziness (e.g., Nijssen et al., 2006; Schultz et al., 2018; Storey \& Cankurtaran, 2016; Wieland, Polese, \& Vargo, 2012). Service innovation requires firms' customers and their service network partners to be more deeply involved (Blindenbach-Driessen \& Van den Ende, 2014; Gadrey, Gallouj, \& Weinstein, 1995; Storey \& Cankurtaran, 2016), which often results in more dynamic, unpredictable, and less standardized processes (Gallouj \& Weinstein, 1997). Consequently, firms often face more efforts to coordinate activities across organizational boundaries, and they are forced to manage highly cooperative and competitive ecosystems (Adner, 2017). As a result of this evolving ecosystem, firms' internal capabilities for service innovation are often insufficient (Paiola et al., 2013); thus, ecosystem-related capabilities play an increasing role in firms' successful servitization journeys (e.g., Kohtamäki et al., 2013; Story et al., 2017). Although scholars are unanimous in their belief that ecosystems are increasingly relevant to explaining organizational outcome, systemic, ecosystem-level perspectives are rarely applied (Kohtamäki \& Rajala, 2016), and research so far has provided few answers about which capabilities are relevant to coping with dynamically evolving ecosystems.

The literature on ecosystems offers various conceptualizations and reflects the diversity of scholars' research traditions and theoretical backgrounds (Jacobides et al., 2018; Lusch \& Vargo, 2014; Teece, 2016; Tsujimoto, Kajikawa, Tomita, \& Matsumoto, 2018). The business ecosystem perspective reflects research on ecosystem dynamics and the relationships between suppliers, complementors, customers, and the focal firm (Adner \& Kapoor, 2010). The multi-actor network perspective expands the business ecosystem perspective and stems from the assumption that relationships among a diverse range of actors and intermediaries can indirectly affect the innovation behaviour of a focal firm (Hienerth, Lettl, \& Keinz, 2014). It reflects the contributions of all entities in the context of innovation, for example, local and national governments, communities, policy-makers, and actors that control public resources.

The multi-actor view is consistent with the "ecosystem-as structure" view of Adner (2017), which suggests focusing more on the role of regulators, influencers, and institutions in order to understand firms' actions. We adopt the view of Adner (2017:40) and define ecosystems as the "alignment structure of the multilateral set of partners that need to interact in order for a focal value proposition to materialize". We selected this view because it starts with the firm's value proposition, examines the relevant capabilities, and describes the alignment of a diverse set of 
ecosystem actors. Hence, it does not constrain the analyses to directly related actors and activities of the focal firm; instead, it expands the boundaries of the analyses to the complex network of a broad range of ecosystem actors and influencers.

\subsection{Dynamic capabilities, service innovation, and ecosystem literature}

The resource-based view of a firm (RBV) centers on the idea that an organization has access to bundles of resources that form the basis for competitive advantage (Barney, 1986). Based on the essentially static nature of the RBV, Teece, Pisano, and Shuen (1997) extended the RBV toward a dynamic capability approach to address changes in the business environment. This perspective has been widely adopted, suggesting that dynamic capabilities are "the firm's ability to integrate, build and reconfigure internal and external competences to address rapidly changing environments" (Teece et al., 1997, 516). We follow the model of Teece (2007) and distinguish dynamic capabilities into three categories that are relevant for sustaining competitive advantage: (i) the capacity to sense and shape opportunities and threats; (ii) the capacity to seize those opportunities; and (iii) the capacity to maintain competitiveness through enhancing and reconfiguring intangible and tangible resources.

Dynamic capabilities facilitate the ability to innovate (Hill \& Rothaermel, 2003; Teece, 2007). This relates to absorptive capacity, which focuses on the relevance of integrating external knowledge, and adaptive capability, which focuses on a firm's ability to align resources and capabilities with environmental changes (Wang \& Ahmed, 2007). Dynamic capabilities embrace different management capabilities that spread across all functions within an organization, including product and service development, human resources, and organizational learning (Lawson \& Samson, 2001). As such, we posit that dynamic capabilities also play an important role in service innovation, because they leverage a firm's potential to adapt to change through innovation (Hill \& Rothaermel, 2003).

Dynamic capabilities also encompass the firm's ability to leverage external networks and ecosystems to adapt to a changing business environment (Teece, 2007; Teece et al., 1997, Eisenhardt \& Martin, 2000). Similarly, the literature on network capabilities explains how firms find, involve, and reconfigure external partners (Ritter, Wilkinson, \& Johnston, 2004). Hence, in this paper we focus on the dynamic capabilities that are needed to facilitate the integration of external actors with relevance to successful service innovation. A few papers have adopted a dynamic capability perspective and investigated the capabilities needed for service innovation (e.g., Raddats, Burton, \& Ashman, 2015; Spring \& Araujo, 2013; Parida, Sjödin, Wincent, \& Kohtamäki, 2014; Huikkola et al., 2016). In particular, the studies of Parida et al. (2014) and Huikkola et al. (2016) provide capability frameworks for service innovation, albeit without any particular ecosystem focus. We are not aware of any study that has applied Teece's (2007) categories to systematically develop a structured set of capabilities focused on firms' ecosystems for service innovation.

\subsubsection{Sensing service-innovation opportunities and threats}

The sensing category of dynamic capabilities refers to the identification and calibration of opportunities by continuously scanning, filtering, and exploring technologies and markets (Teece, 2007). Research provides an understanding of the necessary capability to sense and gather external technological, market, and competitive information (Ritter \& Gemünden, 2003). Firms need to select cooperation partners, which refers to the identification, selection, and acquisition of cooperation partners in the network (e.g., the mutual benefits, compatibility of the strategic goals, and cultural compatibility) (Ritter et al., 2004). This includes the firm's analysis of its own strengths and weaknesses, and of the competitive situation and possible consequences of outsourcing innovation activities (Walter, Auer, \& Ritter, 2006). Additionally, the literature shows that capabilities are needed that cover the sensing of opportunities related to the understanding of regulations, laws, and institutions. For instance, firms are exposed to actors (e.g., local or national governments) that control or allocate public resources, which often constrain the ability to adopt new strategies and business models (Akaka et al., 2013). Especially in the early phase of a service life cycle, firms face a high level of uncertainty regarding a diverse set of stakeholders that potentially affect the innovation behaviour of the focal firm (Cusumano, Kahl, \& Suarez, 2015). Hence, the influence of various stakeholders on the firm's own innovation behavior needs to be analyzed by the focal firm.

\subsubsection{Seizing service-innovation opportunities and threats}

Firms have to address and exploit a broad range of opportunities in order to enhance their value propositions (Teece, 2007). In order to seize opportunities, firms need to promote external networks. This refers to the maintenance of relations with external actors, for example, sufficient internal resources and specific incentive schemes for employees to maintain relations with external contacts. In addition, firms need to configure networks, which emphasizes the legal, time, resource, and formalization aspects of the network (Ritter \& Gemünden, 2003). Firms need to specify, for example, whether cooperation between partners requires a legal regulation, whether the temporal scope of the cooperation is always appropriate for the content of the innovation activity, and whether management of the relationship should be formalized.

Since complementors and complementary assets often influence service innovation, a specific service innovation is often a component of a larger solution, which is affected by a diverse set of actors that have to develop their own innovations or need to adapt norms and routines (Adner \& Kapoor, 2010). This dependency on complementary assets needs to be assessed in order to determine the critical bottlenecks of an innovation (Adner, 2017). In this sense, firms need to integrate various ecosystem actors into decision-making processes, which potentially affect the innovation behavior of the firm. Additionally, it may be helpful to clarify certain roles and responsibilities of all the ecosystem actors and to develop a firm's position in the ecosystem systematically.

\subsubsection{Reconfiguration capabilities for service innovation}

The identification and calibration of opportunities may result in firm growth, but they also often lead to path dependencies (Teece, 2007). In order to sustain profitable growth, firms have to secure a "continuous alignment and realignment of specific tangible and intangible assets" (p. 1340). A major aspect of relationship management relates to the re-evaluation of the strategic fit and the continuous adaption of all cooperation activities. This network reconfiguration relates to the reassessment of actual contributions of the cooperation partners of the applied coordination and management instruments (Ritter \& Gemünden, 2003; Walter et al., 2006). In addition, the literature shows that firms also need to realign the strategic fit between the focal firm and ecosystem actors continuously. The orchestration of the whole ecosystem embraces the management of co-specialization and complementarities and the development of the ability to utilize cospecialized assets (Adner \& Kapoor, 2010).

\section{Methods}

\subsection{Research design}

Considering the complexity of non-value-adding relationships in ecosystems, the case-study approach was chosen to collect in-depth information through interviews and to provide evidence of the practices that the focal firm follows in such relationships (Beverland \& Lindgreen, 2010; Huikkolla, Ylimäki, \& Kohtamäki, 2013). We chose our cases from a quantitative study, suggesting that these cases ensure insights into the phenomenon of ecosystem-related capabilities.

We define high service-innovation intensity as the situation in 


\begin{tabular}{|c|c|c|c|}
\hline Study & 1. Pre-study & 2. Quantitative study & 3. Qualitative study \\
\hline Activities & $\begin{array}{l}\text { - Sample selection } \\
\text { - Measuring service innovation } \\
\text { intensity of each firm ( } \mathrm{n}=181 \\
\text { firms) } \\
\text { - Identifying number of } \\
\text { services through secondary } \\
\text { data analysis (annual } \\
\text { reports, websites, etc.) } \\
\text { - Evaluating service } \\
\text { innovativeness by using } \\
\text { three independent experts }\end{array}$ & $\begin{array}{l}\text { - Performing a survey with } 133 \\
\text { managers from } 28 \text { energy } \\
\text { utilities in Germany } \\
\text { - Using the firm ranking regarding } \\
\text { service innovation intensity for } \\
\text { sample splitting } \\
\text { - High service innovation } \\
\text { intensity (top } 25 \% \text { of the } \\
\text { sample, } \mathrm{n}=10 \text { ) } \\
\text { - Low service innovation } \\
\text { intensity }(\mathrm{n}=18 \text { ) }\end{array}$ & $\begin{array}{l}\text { - Conducting an interview study } \\
\text { with eight firms having a high } \\
\text { service innovation intensity } \\
\text { - Categorizing first and second- } \\
\text { order clusters into the aggregate } \\
\text { dynamic capabilities of sensing, } \\
\text { seizing and reconfiguration }\end{array}$ \\
\hline Result & $\begin{array}{l}\text { - Firm ranking regarding } \\
\text { service innovation intensity }\end{array}$ & $\begin{array}{l}\text { Identification of five dynamic } \\
\text { capabilities that are different } \\
\text { between firms with a high and } \\
\text { a low service innovation } \\
\text { intensity }\end{array}$ & $\begin{array}{l}\text { Identification of } 12 \text { specific } \\
\text { ecosystem-related dynamic } \\
\text { capabilities that can be used in } \\
\text { practice for management of } \\
\text { ecosystems }\end{array}$ \\
\hline
\end{tabular}

Fig. 1. Research design.

Table 1

Example of the measurement of the service-innovation intensity (the list of all 89 services categories is included in the Web Appendix).

\begin{tabular}{llllllll}
\hline \multirow{2}{*}{ Service category } & \multirow{2}{*}{ Service offering } & \multirow{2}{*}{ Service category offered } & \multicolumn{2}{l}{ Service innovativeness dimensions } & \multirow{2}{*}{ Service-innovation intensity } \\
\cline { 5 - 7 } & & & Market & Technology & Firm-internal & Environ-mental \\
\hline 1 & Smart-home services & Yes & 6.33 & 5.67 & 6 & 6.33 & 24.33 \\
2 & Online customer portal & Yes & 2.33 & 1.67 & 2 & 1.67 & 7.67 \\
3 & E-car-sharing & Yes & 5.67 & 5.34 & 5.67 & 6 & 22.67 \\
89 & $\ldots$ & $\cdots$ & $\ldots$ & $\ldots$ & $\ldots$ & $\ldots$ & $\ldots$ \\
Total $^{\text {a }}$ & & & & & & & 54.67 \\
\hline
\end{tabular}

${ }^{a}$ An individual firm's service-innovation intensity with the first three service offerings.

which firms have a broad service-innovation portfolio with, on average, a high degree of innovativeness. According to this definition, we used secondary data to measure the service-innovation intensity of firms by evaluating the number of their service offerings and their innovativeness. In the following quantitative survey-based study, we performed a survey of 133 managers from 28 energy utilities in Germany to examine the differences in the dynamic capabilities between firms that have high or low service-innovation intensity. In the concluding qualitative interview study, we analyzed the ecosystem-related capabilities of eight firms with high service-innovation intensity. Fig. 1 provides an overview of the research design.

We focused on the energy utilities sector because it closely reflects the challenges that firms face when they transition from product to services. Traditionally, the German utility sector was characterized by low-innovation intensity and weak customer orientation (Zentrum für Europäische Wirtschaftsforschung, 2015), as energy (e.g., gas, water, or electricity) is commonly regarded as a commodity (Helms, 2016). However, not least because of competition and changing regulations (e.g., German EEG law), utilities are under pressure and being incentivized to innovate. While the potential for product innovation in commodity markets is limited, service innovations offer a different route to differentiate from the competition (e.g., e-mobility or smart home services).

We identified energy utilities in Germany from the membership listings of professional associations and lists of industry-specific conferences. The firms included in our study had to match three criteria: 1) the core business was heating and electricity production and sales; 2) the firm had to have a minimum of 50 employees and a maximum of 2000 employees; and 3) the firm had to offer a minimum of two service offerings. Applying the selection criteria resulted in the sample of 211 energy utilities, from which 30 were excluded as a result of a lack of data availability.

\subsection{Measuring service-innovation intensity}

To examine ecosystem-related dynamic capabilities, it was necessary to measure the extent to which a firm's service offerings could be considered innovative. To do so, we relied on multiple sources of secondary data, which are usually publicly available and allow replication (Calantone \& Vickery, 2010), including a firm's last annual report, websites, and press articles. Data was collected during a period of nine months, from April to December 2016. In a first step, all service offerings were clustered in 89 categories based on prior service and energy-specific research (Helms, 2016; Kindström \& Ottosson, 2016) (see example in Table 1). In a second step, the innovativeness of these 89 services was assessed by three independent experts using the consensus assessment technique (CAT) proposed by Amabile, Conti, Coon, Lazenby, and Herron (1996). Each service type was described as objectively as possible and the expert evaluated the degree of innovativeness along four dimensions, which follow current innovation research (Atuahene-Gima \& Evangelista, 2000; Schultz, Salomo, \& Talke, 2013): market, technology, firm-internal, and environment newness. The market dimension refers to the offering of a new customer value in comparison with current products and services, the creation of a new market, or the reorganization of the value chain in the industry. The technology dimension describes changes in technology components or principles of new services or products that require a new knowledgebase. The firm-internal dimension relates to adaptions in strategy, 
organization structures, or organizational culture as a result of the innovativeness of a new service. The environmental dimension refers to changes in infrastructure, industry norms, or society values. Each expert was then asked to evaluate the innovativeness for each service category along the four dimensions on a seven-point Likert scale (with the anchors " 1 = low innovativeness" and " $7=$ high innovativeness"). To detect assessment differences between experts, we used the intraclass correlation coefficient (ICC) (McGraw \& Wong, 1996). The ICC value showed an overall value of 0.76 for all dimensions, which was above the threshold of 0.7 needed to secure reliability and validity. To assess each firm's service-innovation intensity, the average expert scores were added up for those service categories that the firm had been offering (see Table 1).

\subsection{Survey}

\subsubsection{Data collection and sample}

The senior managers of the firms were contacted via a direct mailing and telephone campaign explaining the objectives and procedures of the study. Those willing to participate nominated employees involved in innovation tasks in their daily work. Each employee received an individual link to an online survey, including the items for the assessment. By questioning multiple respondents (CEOs, marketing managers, business development managers, and others responsible for service innovation) about network and ecosystem-related capabilities, we were able to reduce common source bias, a frequent problem in empirical research (Page \& Schirr, 2008).

\subsubsection{Measures and properties of the scales}

All indicators of constructs were measured through five-point Likert-type scales using existing and already validated scales. Based on our literature review (see Section 2.2), we examined the capabilities related to network initiation (sensing), network promotion and network configuration (seizing), and network reconfiguration (reconfiguration). We assessed the content validity of the scales via a pre-test in 2 workshops with practitioners from 20 organizations. A complete list of the scales and constructs used in the study is provided in Appendix A. The variables that were assessed from several respondents within an organization were aggregated to a firm-level score by calculating the mean values over their individual responses.

The applied measures were tested for validity and reliability. To assess internal consistency, Cronbach's alpha coefficients were calculated, which ranged between 0.96 and 0.64 at satisfying levels. Principal component analyses (varimax rotation) conducted separately for the items of each construct only extracted one factor with eigenvalues of greater than one, demonstrating their uni-dimensionality (Hair, Black, Babin, \& Anderson, 2009). Convergent validity was checked through exploratory factor analyses and demonstrated by an average variance extracted of $>0.50$ for all constructs (Chin, 1998). Discriminant validity at the construct level was supported by the results that the average variance extracted of each latent variable was greater than the highest squared correlation with all other latent variables (Fornell \& Larcker, 1981). The largest correlation coefficient among the variables is 0.71 , which is below the 0.80 threshold that would give rise to concerns about multicollinearity. Based on the ranking of serviceinnovation intensity identified in the pre-study, we used correlation analyses and $t$-tests to compare firms with high service-innovation intensity (top $25 \%$ of the sample, $n=10$ ) with firms with low serviceinnovation intensity $(n=18)$.

\subsection{In-depth interviews}

To gain a more in-depth understanding of the ecosystem-related dynamic capabilities, we asked the 10 firms identified as having high service-innovation intensity to participate in an explorative interview study. With the exception of 2 companies that were not willing to 
participate, we were able to conduct 11 semi-structured interviews with 8 highly service-oriented firms. The firms were additionally confirmed in the first part of this study as possessing substantial dynamic capabilities and deploying highly innovative services, and hence enabling their organization to servitize. All of the employees that were interviewed were responsible for new service development.

\subsubsection{Data collection and sample}

In-depth interviews were guided by a protocol based on input from three research streams: (i) service literature, (ii) business ecosystem, and (iii) the dynamic capability literature. The interviews covered four topics (see Appendix B): (1) service offerings, (2) ecosystem configuration, (3) drivers and challenges, and (4) dynamic capabilities. We recorded and transcribed all the interviews, which ranged from 45 to $90 \mathrm{~min}$ (Yin, 2009). For reasons of confidentiality, the participating company names were not revealed. Our selected respondents were six innovation managers, three key-account managers in energy services, one marketing manager, and one CEO (see Table 2).

\subsubsection{Data analysis}

For the data analysis of the interviews we followed the procedure proposed by Eisenhardt (1989) and Zimmermann, Raisch, and Birkinshaw (2015) in order to maximize internal and external validity. We examined the empirical data through three distinct stages. First, we started with a deductive approach, reviewing the servitization and ecosystem literature to obtain a basic understanding of the theoretical assumptions. We developed an initial framework for the dynamic capabilities to categorize the prevailing patterns in our empirical cases. Second, we followed inductive reasoning to build the first-order codes from the interviews. In order to ensure the reliability of our results, two researchers independently analyzed the interview transcripts with the aid of the NVivo software tool. In the case of different interpretations of the data, we returned to the interview data, discussed the deviations and built a consensus, which finally led to a list of first-order categories (Miles \& Huberman, 1994). Then, we grouped our first-order categories into second-order categories, which created the basis for the ecosystemrelated dynamic capabilities. Third, we allocated the 12 second-order clusters to the 3 dynamic capabilities, namely, sensing, seizing, and reconfiguration (Fig. 2).

\section{Findings}

\subsection{Survey results - dynamic capabilities and service-innovation intensity}

Table 3 presents mean values and standard deviations, as well as results from the correlation analysis and $t$-tests. Correlation analysis relates firms' service-innovation intensity $(n=28)$ to the five dynamic capabilities, as derived from the literature. $t$-Tests compare the five dynamic capabilities from the group of firms with high $(\mathrm{n}=10)$ and low $(n=18)$ service-innovation intensity. In summary, the results strongly indicate that firms offering many highly innovative services have more pronounced dynamic capabilities (sensing, seizing, and reconfiguration) in comparison to firms with low service-innovation intensity. Correlation coefficients and $t$-test results are significant across all constructs. The results also indicate strong (inter-)correlations between sensing, seizing, and reconfiguration capabilities. This may indicate that those firms that possess dynamic capabilities usually possess all three types of dynamic capability.

\subsubsection{Sensing capabilities}

The results indicate that there is a significant positive correlation between service-innovation intensity and the capability to select cooperation partners $(0.35 ; \mathrm{p}<0.1)$. While the effect is only significant at a $10 \%$ level, the effect is significant at a $5 \%$ level when correlated with the ranking of firms. $t$-Test results confirm the significant difference between the group of firms with high and low service-innovation intensity ( $t=3.56 ; \mathrm{p}<0.01$ ). In other words, firms that offer highly innovative services approach the selection of cooperation partners more systematically, search more for cooperation outside their existing network, and more systematically evaluate the potential of cooperation partners, as well as disclosing their own goals more when communicating with potential partners.

The results also suggest that the degree of service-innovation intensity is positively correlated to the network initiation $(0.35 ; \mathrm{p}<0.1)$ that is supported by the $t$-tests $(t=2.22 ; \mathrm{p}<0.05)$. These results thus indicate that, compared to firms offering only some and low innovative services, those offering more and highly innovative services analyze their strengths and weaknesses more, as well as the company's environment. Highly service-oriented firms also investigate more the possible consequences of (partially) outsourcing innovation activities and more clearly define goals for cooperation activities.

\subsubsection{Seizing capabilities}

With respect to the seizing of opportunities, the survey results suggest that the degree of service-innovation intensity is positively correlated to the network configuration $(0.45 ; \mathrm{p}<0.05)$, which is supported by the $t$-test results $(t=2.74 ; \mathrm{p}<0.05)$. These findings suggest that firms offering more and highly innovative services draw more attention to clearly regulating cooperation in terms of contractual arrangements (e.g., IP rights, scope of information exchange, sanctions), duration (e.g., temporarily limited cooperation), and the resources that cooperation partners commit (e.g., type and amount), as well as project management and reporting.

We also tested for the relationship between service-innovation intensity and network promotion. The findings reveal the strongest positive correlation $(0.55 ; \mathrm{p}<0.01)$, also supported by $t$-test results $(t=3.09 ; \mathrm{p}<0.01)$. This suggests that firms offering many highly innovative services have more clearly defined contact persons responsible for maintaining external relations, have specific job descriptions for those roles, allocate sufficient resources for carrying out these activities, have incentive schemes in place to motivate employees to maintain external relations, and encourage employees to be open to external input in general.

\subsubsection{Reconfiguration capabilities}

Regarding the capabilities needed to reconfigure ecosystems, the correlation results do not indicate a significant relation. In contrast, $t$ test results indicate a significant difference $(t=2.62$; $\mathrm{p}<0.05)$ between the group of firms offering many highly innovative services and those with low service-innovation intensity. While these results appear less robust, based on the $t$-test results, we can, however, conclude that firms offering many highly innovative services better ensure that objectives, project progress, and decisions are known and accessible to team members, and regularly compare the contributions of cooperation partners. Moreover, cooperation partners regularly attend joint meetings and report results, know what information is passed on to partners, and regularly evaluate cooperation activities.

\subsection{Interview results - ecosystem-related dynamic capabilities}

From analysing 11 in-depth interviews with 8 firms with high service-innovation intensity, we identified a set of 12 ecosystem-related capabilities, that is, 4 sensing, 4 seizing, and 4 reconfiguration capabilities (Fig. 2).

\subsubsection{Ecosystem-related sensing capabilities}

4.2.1.1. Creating an open mindset for a diverse set of different ecosystem partners. The literature has shown that a diverse set of stakeholder relationships are relevant to a focal firm (Akaka et al., 2013; Teece, 2007). Likewise, our results indicate the importance of creating an open mindset for collaboration with a diverse set of ecosystem actors. The interviewed firms stated that they gather in meetings to discuss trends 


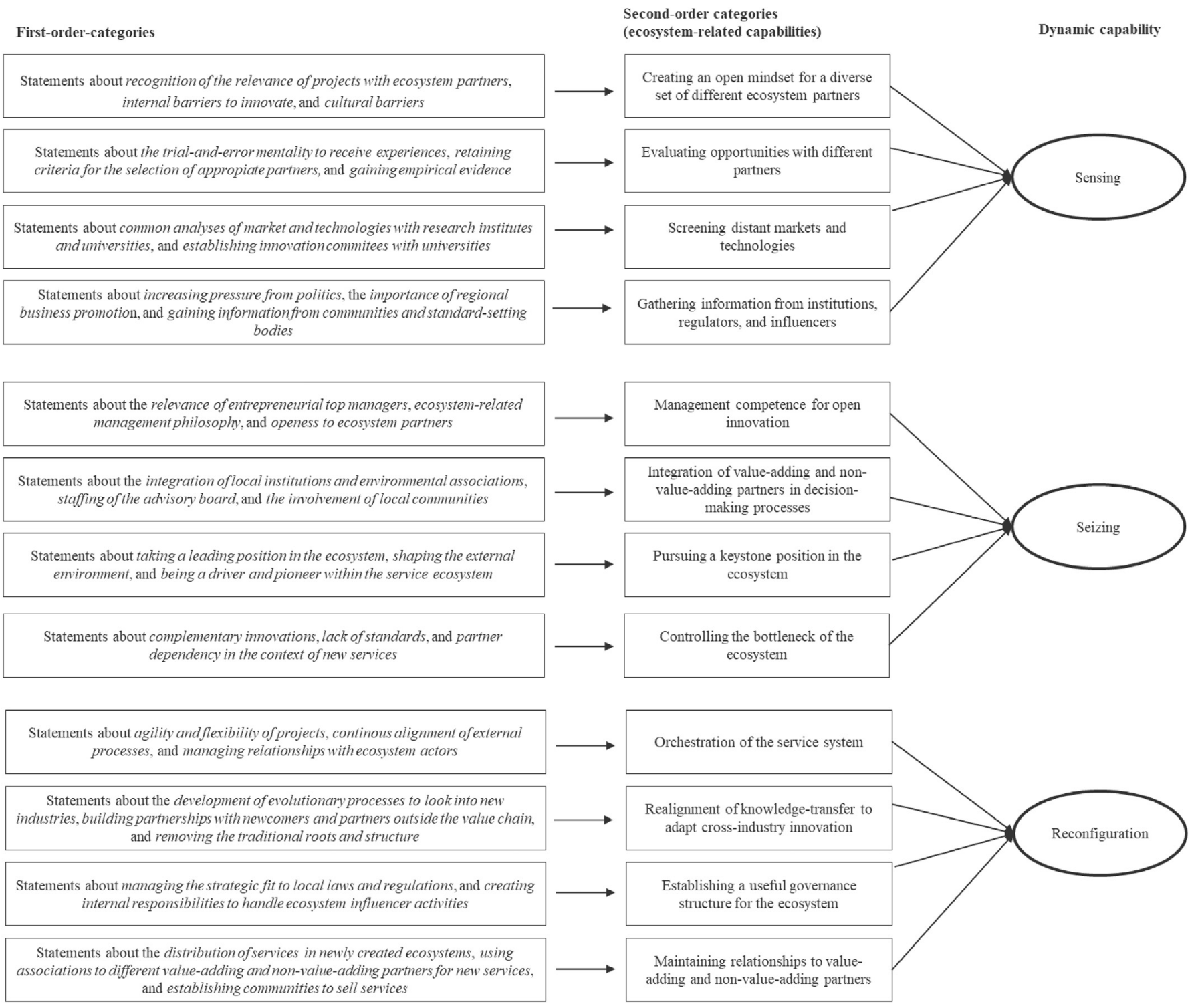

Fig. 2. Identified ecosystem-related dynamic capabilities.

Table 3

Descriptive statistics and univariate tests.

\begin{tabular}{|c|c|c|c|c|c|c|c|c|c|c|c|c|c|c|}
\hline & \multirow[t]{2}{*}{ Variables } & \multicolumn{10}{|c|}{ Overall correlations, means, standard deviations } & \multirow{2}{*}{$\begin{array}{l}\text { High service- } \\
\text { innovation intensity } \\
(N=10) \\
\text { Mean }\end{array}$} & \multirow{2}{*}{$\begin{array}{l}\text { Low service- } \\
\text { innovation intensity } \\
(N=18) \\
\text { Mean }\end{array}$} & \multirow{2}{*}{$\begin{array}{l}t \text {-Test for equality } \\
\text { of means }\end{array}$} \\
\hline & & Mean & S.D. & 1 & 2 & 3 & 4 & 5 & 6 & 7 & 8 & & & \\
\hline 1 & $\begin{array}{l}\text { Rank service-innovation } \\
\text { intensity }\end{array}$ & & & 1 & & & & & & & & & & \\
\hline 2 & Service-innovation intensity & 183.60 & 107.21 & $0.96^{* * *}$ & 1 & & & & & & & & & \\
\hline 3 & $\begin{array}{l}\text { Selection of cooperation } \\
\text { partners (sensing) }\end{array}$ & 3.30 & 0.68 & $0.39 *$ & $0.35^{\dagger}$ & 1 & & & & & & 3.80 & 3.02 & $3.56^{*}$ \\
\hline 4 & Network initiation (sensing) & 2.95 & 0.79 & $0.41^{*}$ & $0.35^{\dagger}$ & $0.71^{\text {*** }}$ & 1 & & & & & 3.37 & 2.71 & $2.22 *$ \\
\hline 5 & $\begin{array}{l}\text { Network configuration } \\
\text { (seizing) }\end{array}$ & 2.92 & 0.58 & $0.39 *$ & $0.45^{*}$ & $0.55^{* *}$ & $0.73^{* *}$ & 1 & & & & 3.27 & 2.71 & $2.74 *$ \\
\hline 6 & Network promotion (seizing) & 2.40 & 0.60 & $0.55^{* *}$ & $0.55^{\text {*** }}$ & $0.72^{* *}$ & $0.59^{* *}$ & $0.48^{*}$ & 1 & & & 2.85 & 2.19 & $3.09^{* *}$ \\
\hline 7 & $\begin{array}{l}\text { Network reconfiguration } \\
\text { (reconfiguration) }\end{array}$ & 3.13 & 0.57 & 0.25 & 0.25 & $0.55^{\text {*** }}$ & $0.68^{* * *}$ & $0.72^{* *}$ & 0.36 & 1 & & 3.44 & 2.95 & $2.62^{*}$ \\
\hline
\end{tabular}

${ }^{\circ}=$ Spearman correlation; $\mathrm{M}=$ mean; $\mathrm{SD}=$ standard deviation; $\mathrm{n}=28$.

Correlations concerning the ranking of service innovation intensity were multiplied by -1 .

$* * \mathrm{p}<0.01$.
$* \mathrm{p}<0.05$
$+\mathrm{p}<0.10$ 
and external actors, like interest communities. This includes voicing visionary or disruptive concepts, such as innovative power free-of-cost services offered in approximately ten years, and how these could potentially be made to work jointly with external partners. A key account manager of firm 8 said: "In the beginning of our service journey, we were completely overwhelmed with the new processes and the different actors. And the problems are increasing, if you attempt to promote these services internally. You need to take these people with you. "In summary, in order to develop highly innovative services within a broader range of ecosystem actors, firms need to allow and motivate employees to sense new opportunities.

4.2.1.2. Evaluating opportunities with different partners. The results show that firms offering many highly innovative services follow cooperation approaches of learning, interpretation, and probing of customer needs and technological opportunities. For instance, an innovation manager from firm 4 said of a cross-firm initiative: "During our smart-meter service development, it was not clear what the standards of the smart meter would look like. Together with different ecosystem partners, we wanted to gain first insights and to establish a foundation for the decision a few years later. This extended our experiences and prepared us for the final decision to invest." Several firms stated that they need to convince and enable relevant partners such as the local government and local craft communities to provide relevant complementary services for, for example, smart-home solutions. In short, firms possessing high service-innovation intensity often use initial investment in collaborative projects with other ecosystem actors to probe customer needs and to assess and extend the external resources in the ecosystem.

4.2.1.3. Screening distant markets and technologies. Our results indicate that service-innovation-intense firms often sense opportunities through scanning and screening markets and technologies with research institutes and universities. Universities are mentioned as an aggregator and organizer of knowledge or as a channelling partner to organize relationship platforms. The latter are described as interest alliances, which include diverse partners on a topic. An innovation manager from firm 6 said: "We have implemented an advisory board for service innovation, which includes universities. The reason behind [this] is to gather feedback, opinions and recommendations from leading academics." In summary, projects with universities can be seen as an investment, which may lead to a deeper service understanding of new opportunities.

4.2.1.4. Gathering information from institutions, regulators, and influencers. The firms offering many highly innovative services specifically mentioned their need to understand what politicians and the government are requesting from them, as well as the influences of non-governmental organizations (NGOs) looking at green energy production. The following statements from a marketing manager underline that capabilities for service innovation go beyond intraorganizational boundaries and increasingly relate to the broader environment of the focal firm: "The greatest chaos concerns politics. If they nowadays pass a law to support a certain technology or service, all firms jump on the bandwagon. But if they revise the law a few years later, we frequently cannot leave it." In short, in order to identify and shape opportunities, firms with high service-innovation intensity constantly explore and screen the broader ecosystem, which involves local (e.g., municipal communities) and distant stakeholders (e.g., national governments).

\subsubsection{Ecosystem-related seizing capabilities}

4.2.2.1. Management competencies for open innovation. The descriptions from the interviews vary regarding seizing capabilities. In some of the interviewed organizations, gaining management support was seen as trivial, which may have been biased by the fact that we had only highly innovative firms in the sample. However, there was mention of aligning culture and individual people internally, but also toward external partner firms. For instance, an innovation manager from firm 3 pointed out: "At the end of the day, the organization has to take care of the relations with other ecosystem actors. We need the willingness to actively deal with the relevant stakeholders, associations and institutions to manage external collaborations." The seizing of external opportunities is stated to start internally, where the firm rearranges and organizes itself and then looks externally for ideal optimization of the exchange points, also considering whether the external actor (e.g., supplier) still fits and delivers value. This is not considered trivial. For instance, the CEO from firm 7 said: "The biggest difficulty is to adapt the process-oriented system infrastructure of our firm toward an agile project-oriented system. These systems need to be realigned with know-how from outside." In short, innovation management competencies, and a supportive top management toward a diverse set of ecosystem actors, appear to be important for seizing service opportunities.

4.2.2.2. Integration of ecosystem actors in decision-making processes. The findings reveal that service-intense firms integrate ecosystem actors in decision-making processes during the implementation of new services. The interviewees described that they had taken into account external actors, such as local institutions, environmental associations, advisory boards, and local communities, or used them for their own purpose internally to drive decisions. One example was to integrate environmental NGOs in the development of eco-friendly power products and services. The expertise added by the external partner offers significant advantages through the direct input and idea exchange. Another example relates to the interview with a key account manager from firm 5, who said: "We have an energy-related community in our city, which is negatively related to some of our energy projects. You have to take this community on board with you. Then they are always positive for new service activities."

4.2.2.3. Pursuing a keystone position in the ecosystem. Firms offering highly innovative services appear to be increasingly embedded within ecosystems, and they are additionally developing a more holistic strategy that goes beyond organizational boundaries. This appears to be consistent with research from Iansiti and Levien (2004), who stated: "Strategy is becoming, to an increasing extent, the art of managing assets that one does not own" (p. 1). In this respect, Dhanaraj and Parkhe (2006) posit that keystone firms manage knowledge mobility, focus on relevant innovation topics, and create network stability. In this vein, other scholars highlight the role of the "architect" (Gulati, Puranam, \& Tushman, 2012) in shaping the emergence of an ecosystem (Teece, 2007). Similarly, the CEO of company 5 pointed out: "I would consider us a leader for new services in our ecosystem, sometimes additionally as an incubator to increase the maturity of the service." In summary, the highly innovative firms expressed an urge to be the driver and to be seen as the innovator within their ecosystem. They therefore stated that they were driving innovation discussions and aiming to be as active as possible. It was also stated that it was positive to be seen as an innovator by other actors in the industry, as they would choose to approach them for innovation collaborations.

4.2.2.4. Controlling the bottleneck of the ecosystem. The results show that highly innovative firms seek information and drive change in the face of bottlenecks, which are seen as hindering large innovations and changes. This is consistent with the research of Adner and Kapoor (2016), who stress that the success of innovation often depends on the challenges that complementors face in their ecosystem. For instance, a key account manager from firm 3 stated: "We have implemented technology from our supplier, Siemens, but we are dependent on this company, [so] what should we do if Siemens is planning to change its technology standards? This would be a mess for our firm." The innovation manager from firm 3 similarly said: "So we don't have to do everything ourselves. If I cannot do everything myself, then we must at least be able to understand and manage things. [...] This means that you must be willing to actively deal with the relevant 
Table 4

Firm quotes related to each capability area.

\begin{tabular}{|c|c|c|c|}
\hline Firm & Sensing & Seizing & Reconfiguration \\
\hline Firm 1 & $\begin{array}{l}\text { Strengthening the increasing pressure from politics, } \\
\text { standard-setting bodies, and communities, and the } \\
\text { importance of gathering information from them }\end{array}$ & $\begin{array}{l}\text { Focusing on taking a leading position and being } \\
\text { a driver and pioneer within the ecosystem }\end{array}$ & $\begin{array}{l}\text { Strengthening the effect that ecosystem actors change over } \\
\text { time, and therefore it is important to frequently realign } \\
\text { relationships to value-adding and non-value-adding } \\
\text { partners }\end{array}$ \\
\hline Firm 2 & $\begin{array}{l}\text { Describing the relevance of the trial-and-error mentality } \\
\text { to receive feedback from customers and other network } \\
\text { partners }\end{array}$ & $\begin{array}{l}\text { Strongly integrating value-adding and non- } \\
\text { value-adding partners in their internal decision- } \\
\text { making processes }\end{array}$ & $\begin{array}{l}\text { Describing that they act more as brokers and mediators in } \\
\text { their network; they orchestrate networks and maintain and } \\
\text { revitalize them }\end{array}$ \\
\hline Firm 3 & $\begin{array}{l}\text { Strengthening the importance of projects with ecosystem } \\
\text { partners to create an adequate mindset for service } \\
\text { development }\end{array}$ & $\begin{array}{l}\text { Strengthening the willingness to actively deal } \\
\text { with the relevant stakeholders, associations, } \\
\text { and institutions to manage external } \\
\text { collaboration }\end{array}$ & $\begin{array}{l}\text { Strengthening the relevance of associations to different } \\
\text { value-adding and non-value-adding partners in order to } \\
\text { continuously distribute services in newly created } \\
\text { ecosystems }\end{array}$ \\
\hline Firm 4 & $\begin{array}{l}\text { Describing the relevance of the trial-and-error mentality } \\
\text { to receive feedback from customers and other network } \\
\text { partners }\end{array}$ & $\begin{array}{l}\text { Focusing on the relevance of the top managers' } \\
\text { mindset, which is aligned on collaboration and } \\
\text { cooperation }\end{array}$ & $\begin{array}{l}\text { Strengthening the relevance of managing relationships } \\
\text { with a diverse set of communities and standard-setting } \\
\text { bodies }\end{array}$ \\
\hline Firm 5 & $\begin{array}{l}\text { Strengthening the relevance of common analyses of the } \\
\text { market and technologies to research institutes and } \\
\text { universities }\end{array}$ & $\begin{array}{l}\text { Strongly integrating value-adding and non- } \\
\text { value-adding partners (especially universities) } \\
\text { in their internal decision-making processes }\end{array}$ & $\begin{array}{l}\text { Describing that they separated the new service business } \\
\text { from the daily business; they realigned the corporate } \\
\text { structure by establishing a start-up company in their own } \\
\text { firm }\end{array}$ \\
\hline Firm 6 & $\begin{array}{l}\text { Describing the effect of the implementation of an } \\
\text { advisory board of different institutions from their } \\
\text { ecosystem to gather feedback, opinions, and } \\
\text { recommendations }\end{array}$ & $\begin{array}{l}\text { Describing partner dependency in the context of } \\
\text { new services and therefore the necessity to } \\
\text { control the bottleneck }\end{array}$ & $\begin{array}{l}\text { According to the legal framework, they were focusing on } \\
\text { establishing a useful governance structure for the } \\
\text { ecosystem by continuously managing the strategic fit to } \\
\text { local laws and regulations }\end{array}$ \\
\hline Firm 7 & $\begin{array}{l}\text { Strengthening the increasing pressure from politics, } \\
\text { standard-setting bodies, and communities, and the } \\
\text { importance of gathering information from them }\end{array}$ & $\begin{array}{l}\text { Focusing on the difficulties to adapt agile } \\
\text { project-oriented systems. These systems were } \\
\text { realigned with know-how from outside }\end{array}$ & $\begin{array}{l}\text { Focusing on establishing a useful governance structure for } \\
\text { the ecosystem by continuously managing the strategic fit } \\
\text { to local laws and regulations }\end{array}$ \\
\hline Firm 8 & $\begin{array}{l}\text { Explaining the difficult financial situation at the } \\
\text { beginning of the service journey and the positive effect of } \\
\text { different insights from ecosystem actors on service } \\
\text { success }\end{array}$ & $\begin{array}{l}\text { Strongly integrating value-adding and non- } \\
\text { value-adding partners in decision-making } \\
\text { processes for service development }\end{array}$ & $\begin{array}{l}\text { Describing that they act more as brokers and mediators in } \\
\text { their network; they orchestrate networks and maintain and } \\
\text { revitalize them }\end{array}$ \\
\hline
\end{tabular}

customers and associations and institutions, also in a positive sense." Overall, the interviewees reported the relevance of including different ecosystem actors in the service system and stressed the requirement to orchestrate the process, both internally and externally. In short, firms have to track and, if possible, control different ecosystem influencers, regulators, and standard-setting bodies that potentially affect innovation behaviour.

\subsubsection{Ecosystem-related reconfiguration capabilities}

4.2.3.1. Orchestration of the service system. Consistent with previous studies (e.g., Fischer et al., 2010; Kindström et al., 2013), our results indicate that highly innovative firms re-evaluate and re-orchestrate the whole ecosystem of suppliers, customers, and other actors. One innovation manager from firm 1 said: "This ecosystem must also remain alive. Interests may change, the partners may also change. So that's the way it is, they may have a common interest, they may be doing smart meters together. But then the topic somehow becomes so operative that you have to decide. Then perhaps five actors in a network will choose one direction and four the other." This relates to the necessity to continuously evaluate the roles and contributions of external stakeholders, which should result in a continuous alignment of external processes and, if necessary, in the replacement of innovation partners.

4.2.3.2. Continuous realignment of the ecosystem. The highly innovative firms have demonstrated that they are prepared to seek innovations beyond their traditional industry. Hence, firms need to continuously find and integrate new partners from outside the current ecosystem. Furthermore, the firms need to convince existing ecosystem partners to support their radical innovation ideas and to join collective investment strategies. As such, there is a certain communication task at hand, thereby informing existing and potential new partners and increasing the partner's innovation ability, and, foremost, motivation to change. In this regard, realignment of the ecosystem partners and their routines with future innovation tasks is required on a regular basis. The innovation manager from firm 3 said: "It was a strategy to present our new service in the network and broader ecosystem. We have seen relatively quickly that there was a great demand and the idea was to create broad networks in order to continue to roll out, even beyond our traditional customers. " Doing so allows the future of the ecosystem, and potentially the relevant market, to be influenced, as the CEO of firm 7 said: "If you, as a municipal utility, get behind the wheel, then you can also control. But you must also do it actively yourself."

4.2.3.3. Establishing a useful governance structure for the ecosystem. The results indicate that highly innovative firms need to understand and evaluate local investments and need to secure governmental support mechanisms for new ventures. Most service-innovation-intense firms use, and collectively improve, the services of local cluster management agencies, associations, and regional development agencies. Since a single firm is not able to, and should not, dominate the entire ecosystem, such collective initiatives include independent and sometimes competing actors: "We act more as brokers and mediators. Electricity does not always have to come from us. We build networks and maintain and revitalize them. Also in the housing industry, for example, where we have become a good and welcomed partner, because we are also promoting certain topics here that others do not." In summary, a key to sustained service innovation seems to be the ability to set up governance structures in the regional ecosystem that help to coordinate actors, as well as their regulatory environment.

4.2.3.4. Maintaining ecosystem-related relationships. Managing, as well as developing, the ecosystem service innovation is a demanding task that requires specific capabilities. The management of service innovations involves instruments and processes that are different from the daily business (Schultz et al., 2018) and benefits from specific information technology to collaborate with heterogeneous stakeholders (Kroh, Lütjen, Globocnik, \& Schultz, 2018). As such, the innovation manager from firm 5 said: "To successfully implement service systems, we separated the new service business from our daily business. It was vitally important that we realigned our corporate structure by establishing a start-up company in our own firm." An innovation manager from firm 1 pointed out the need to "create internal 
responsibilities to cope with new regulations and laws". Another manager focused on the regulatory aspects: "The legal framework in Germany is quite difficult, as there are different restrictions. We need to establish clever units so that we can react to this." These dedicated organization units allow continuous learning with regard to service ecosystem capabilities, as well as coping with the inconsistencies with the current operations.

Table 4 summarizes the firm's quotes related to each capability area.

\section{Discussion}

Combining a dynamic capability and ecosystem perspective, the aim of this study was to detail our understanding of ecosystem-related capabilities that firms require for service innovations. Our results strongly indicate that external relationships with various directly and indirectly linked ecosystem stakeholders play a central role in successfully developing and delivering service innovations. Such relationships include not only "traditional" open innovation partners, such as suppliers and customers or users, but also providers of public resources. The latter comprise regulators, local and national governments, communities, industrial associations, and research and teaching institutions, among others.

The results of the quantitative study show that firms with high service-innovation intensity possess stronger network-related dynamic capabilities than firms with lower service-innovation intensity. Using multi-informant data on organizational capabilities and objective data on the extent of service activities of the analyzed firms, the findings indicate that firms need to professionalize their network management in order to servitize successfully. Firms need to identify and select cooperation partners based on a systematic analysis, to set up clear structures, roles, and processes within the network and within the firm itself, and to regulate and evaluate cooperation activities continuously. Adapting the three Teece (2007) categories for dynamic capabilities to the ecosystem perspective, we complemented these findings with a qualitative analysis of eight firms with a high service-innovation intensity. We identified a set of 12 ecosystem-related dynamic capabilities that could be helpful for practice in order to develop and reconfigure business ecosystems for successful service-innovation delivery.

\subsection{Research implications}

This study makes four contributions to the academic literature, with associated implications for further research.

First, we extend research that concentrates on the dynamic capabilities that service innovators develop in order to cope with serviceinnovation challenges (e.g., Fischer et al., 2010Kindström et al., 2013). Combining dynamic capabilities with an ecosystem perspective, we derive a set of 12 capabilities ( 4 sensing, 4 seizing, and 4 reconfiguration capabilities). While we are not aware of any prior framework that has been structured along the three Teece (2007) categories, the capabilities in our set partly overlap with those in previously proposed frameworks, such as the ones by Parida et al. (2014) and Huikkola et al. (2016). For instance, the network management capability in Parida et al.'s (2014) framework, with its dimensions (e.g., involving new and existing partners, developing partner understanding), relates to our seizing-related capabilities (e.g., evaluating opportunities with different partners). Moreover, what they label "service delivery network management" (e.g., extending the involvement of delivery partners) relates to our sensing capabilities (i.e., the integration of value-adding and non-value-adding partners in decision-making processes). Future studies may want to investigate and cross-validate the different frameworks, possibly in other empirical settings.

Second, our results indicate that firms should consider a broader set of stakeholders in service-innovation endeavors than suggested in previous studies. Most studies applied a network perspective focusing mainly on actors with direct relationships to a service innovator (Ford and Gadde, 2003; Akaka et al., 2013; Mele et al., 2015). We suggest that a firm's innovation network is a component of a broader ecosystem (Frow et al., 2016), and that the ecosystem concept may extend the "somewhat static network approach" (Lusch \& Vargo, 2014: 161), as it conveys the entirety of the dynamic exchange processes of activity flows within networks by focusing on the value proposition of the focal firm (Adner, 2017). Employing the ecosystem perspective widens the network perspective by integrating actors over which "the focal firm have no control, and with whom they have no direct contact" (Adner, 2017: 44). These actors (e.g., communities, city governments, regulators, standard-setting bodies) may have no formal obvious role in innovation activities, but they indirectly affect the innovation behavior of the focal firm (one may call these actors weak complementors). Our results show that firms offering more innovative services have specific ecosystem-related capabilities that allow them to integrate a wider set of ecosystem actors into innovation processes. Further research may investigate the specific role of those weak complementors.

Third, our study provides a refined conceptualization and a finergrained measurement of the construct "degree of service-innovation intensity". We believe that service-innovation intensity is a useful indicator for the servitization efforts of firms. This novel approach responds to scholars calling for a new and improved measurement of service strategies (Kohtamäki et al., 2013). Prior studies have mainly measured service offerings by using dichotomous service items (e.g., Homburg, Fassnacht, \& Günther, 2003) or service-offering categories (Kohtamäki et al., 2013; Kowalkowski, Windahl, Kindström, \& Gebauer, 2015; Windahl \& Lakemond, 2010) as proxies for the degree of servitization. We argue that the measurement of service-innovation intensity (as an initial step for servitization) requires consideration of the number of services offered, weighted with the innovativeness of the services in a firm's portfolio.

Fourth, this study shows that ecosystems play an important role in service innovation in the context of energy utilities. By researching energy utilities, we extend the servitization discussion to industries that might not be considered "traditional" manufacturing industries, but which are also regarded as industries in which firms find it difficult to maintain competitiveness through product innovation and differentiation, for example, mature industries with a high degree of commoditization. Given that many utilities are increasingly shifting from being commodity-providers toward becoming complex service or product-service system-providers (Helms, 2016; Kindström \& Ottosson, 2016; Lütjen et al., 2017), we believe that this empirical setting can offer numerous insights for a better understanding of dynamic capabilities for service innovation. Future studies may further study the relations of service innovation, servitization, and firm ecosystems in this or other commodity industries.

\subsection{Managerial implications}

This study has practical implications, predominantly for managers of product-centric firms who embark on a journey to develop and deliver innovative services. Understanding the dynamic capabilities that firms need for successful service innovation should help managers to reconfigure their firm's ecosystem. The findings of our study may be summarized according to the following managerial guidelines.

First, firms should sense, map, and identify the relevant external ecosystem actors that are necessary for developing and delivering innovative services, including their value contributions. Thereby, they should take a broader view that also considers the non-direct valueadding stakeholders (e.g., local government, user communities). Second, managers should assess the gap between the existing (current) and required (new) ecosystem configuration and develop strategies to close this gap. Third, firms should seize opportunities by involving indirect external ecosystem actors in the decision-making process and activating non-direct value-adding relationships by employing co-evolutionary development processes. Fourth, managers should continuously re-evaluate and reconfigure the external relationships and the 
entire ecosystems along the servitization journey. Fifth, firms should build and maintain the capabilities by establishing relationship functions and promoting an open mindset in the whole organization.

Although we derived insights from the German energy utility industry, other companies are also increasingly reconfiguring their ecosystems to deliver innovative services. An example of how firms are reconfiguring their ecosystems is Daimler's Car2Go car-sharing solution (Tietze, Schiederig, \& Herstatt, 2013). In order to offer this advanced, functional product-service system (or complex service solution), Daimler first needed to modify the product that was used to deliver the service; in other words, the company needed to embed telematics solutions in its vehicles to be able to govern the service cost-effectively. More importantly, Daimler had to partner with an ecosystem complementor that already possessed the capabilities to effectively operate car-sharing solutions, for example, relocating vehicles regularly to match customer demand, servicing, refuelling, and cleaning vehicles. For that purpose, Daimler formed a joint venture with Europcar, a major car rental company with operations across many major cities. After Daimler developed the necessary competencies in-house, the firm re-evaluated the value of the external partner Europcar and terminated this collaboration. The next, and currently last, step of the business ecosystem evolution was that Daimler integrated its car-sharing activities in a joint venture (SHARE NOW) with its biggest competitor, the BMW Group.

As illustrated by the Car2Go example, our results imply that managers require not just a perspective to sense, seize, and reconfigure value-adding $\mathrm{B} 2 \mathrm{~B}$ or $\mathrm{B} 2 \mathrm{C}$ relationships, but also a broader ecosystem perspective to develop and orchestrate an entire ecosystem, which includes non-direct value-adding relationships with institutions, communities, and regulators. In the Car2Go case, Daimler had to agree specific parking rules for its vehicles with local governments in order to successfully deploy its service. For instance, in certain cities Car2Go members can park their vehicles for free on otherwise fee-based parking spaces, which are owned by the local government.

Additionally, practitioners have suggested servitization approaches as relevant strategies to counteract "commoditization" in manufacturing industries, while prior research has paid little attention to investigating what manufacturing industries could learn from commodity industries, where products and services have a high level of standardization. However, what we see today is that products and services that were originally innovative also often evolve into commodities. For instance, products such as television sets or mobile phones were seen as breakthrough innovations when they first appeared on the market, but nowadays they are perceived as quasi-commodities. Indeed, various indicators such as decreasing customer loyalty, increasing price-based buying decisions, standardization of technologies, and new market players from lower-cost countries signify the emergence of a commodity trap in manufacturing industries (Roland Berger, 2014). What we observe in our study is that a wide range of levers is available to escape the commodity trap, that is, by transforming their business models toward service ecosystems. This embraces the integration of direct value-adding and non-direct valueadding stakeholders in the development of (predictive) maintenance packages, data-driven services, and functional services.

In summary, our findings imply that firms require capabilities so that they can pursue a keystone position that allows them to orchestrate an ecosystem, including actors with non-direct value-adding contributions (e.g., institutions, influencers, and regulators). Moreover, they require capabilities that enable and empower them to reconfigure their ecosystem, meaning forging new relationships but also discontinuing existing relationships.

\subsection{Limitations and suggestions for further research}

Our study has limitations that need to be considered when interpreting the results. First, this study design is limited with regard to the causality of relationships between variables. The research builds on descriptive evidence and thus does not allow for conclusions to be drawn about the causal mechanisms. Accordingly, future studies should employ research designs, such as longitudinal ones, which allow the causalities of dynamic capabilities, the ecosystem, and service innovation to be examined. Despite using independent secondary data to measure service-innovation intensity, the validity of our indicator of the dependent variable may still be limited. The publicly available sources that were analyzed, such as annual reports, websites, and the local press, may not cover all service activities and may overstate the economic relevance of the services offered by firms. For example, the measurement might be distorted for service activities that firms treated confidentially to avoid competition. Nevertheless, we expect that most relevant services should lead to a higher degree of communication in websites, news articles, and annual reports to gain new customers and increase market attraction (Benedettini et al., 2017). Our way of measuring also does not consider the share of revenue generated from the service versus the product business. Future research may complement the results by relying on primary data. Such additional data may also help the performance effect of each service offering to be measured. Finally, we examined dynamic capabilities in the context of a single industry, and we assume that the results apply in other industries. However, our results are based on cases from the specific commodity energy utilities industry, where even greater challenges in the context of servitization can be expected, and which may be different to other, for example, more innovative, industries. Hence, a replication in other industries would extend the generalizability of the results and represent a promising avenue for scientific research.

Supplementary data to this article can be found online at https:// doi.org/10.1016/j.jbusres.2019.06.001.

\section{Acknowledgements}

The work described in this paper was substantially supported by the Gesellschaft für Energie Klimaschutz Schleswig-Holstein (EKSH, Association for Energy and Climate Protection Schleswig-Holstein).

\section{Appendix A. Measures and corresponding factor loadings}

\begin{tabular}{|c|c|c|}
\hline Construct & Items & $\begin{array}{l}\text { Factor } \\
\text { loading }\end{array}$ \\
\hline Sensing & $(\alpha=0.88 ; \operatorname{AVE}=0.74)$ & \\
\hline Selection of Cooperation Partners (Sources: Walter et al., 2006; & $(1=$ strongly disagree, $5=$ strongly agree $)$ & \\
\hline \multirow[t]{5}{*}{ Ritter \& Gemünden, 2003; Ritter et al., 2004) } & Before we decide to select a network partner ... & \\
\hline & ...we systematically identify potential cooperation partners. & 0.94 \\
\hline & ...we search for potential cooperation partners, even outside the existing network. & 0.86 \\
\hline & $\begin{array}{l}\text {...we systematically evaluate potential cooperation partners, e.g., the mutual benefits of coopera- } \\
\text { tion, the compatibility of our respective strategic goals and cultural compatibility. }\end{array}$ & 0.87 \\
\hline & $\begin{array}{l}\text { When communicating with potential cooperation partners for the first time, we fully disclose our } \\
\text { own goals for the cooperation. }\end{array}$ & 0.78 \\
\hline
\end{tabular}


Sensing

Network Initiation (Sources: Walter et al., 2006; Ritter \& Gemünden, 2003; Ritter et al., 2004)

Seizing

Network Configuration (Sources: Walter et al., 2006; Ritter \& Gemünden, 2003; Ritter et al., 2004)

Network Promotion (Sources: Walter et al., 2006; Ritter \& Gemünden, 2003; Ritter et al., 2004)

Reconfiguration

Network Reconfiguration (Sources: Ritter et al., 2004; Walter et al., 2006; Ritter \& Gemünden, 2003; Ritter et al., 2004)

$(\alpha=0.92 ;$ AVE $=0.81)$

( 1 = strongly disagree, 5 = strongly agree $)$

Before we cooperate with external partners on innovation activities ...

...we analyze our own strengths and weaknesses with regard to the relevant project.

...we analyze the company environment, e.g., the competitive situation, infrastructure, and funding 0.93 possibilities.

...we analyze the possible consequences of (partially) outsourcing innovation activities, e.g., the $\quad 0.86$ consequences for our core competencies, image, and internal barriers.

We define clear goals for each cooperation activity, e.g., innovation result, contribution to the 0.85 competitive situation, temporal goals, and the use of resources.

$(\alpha=0.84 ;$ AVE $=0.57)$

( 1 = strongly disagree, $5=$ strongly agree $)$

The legal aspects of cooperation between the cooperation partners are always clearly regulated, e.g., $\quad 0.74$ joint patent utilization, scope of information exchange, and the contractual form of cooperation.

Sanctions for conduct that is contrary to agreement form a component of our cooperation contracts. 0.78

The duration of cooperation is clearly regulated for each innovation activity, e.g., temporally limited 0.75 project cooperation and long-term cooperation in a business area.

The temporal scope of cooperation is always appropriate for the content of the innovation activity, 0.78 e.g., limited project cooperation for incremental further development.

The type and amount of resources that each cooperation partner is expected to provide are always 0.79 clearly regulated.

The systems of project management and reporting are clearly regulated for all cooperation.

$(1=$ strongly disagree, $5=$ strongly agree $)$

We have defined the contact persons responsible for maintaining external relations.

The role of maintaining external contacts (such as the systematic collection of information and

internal dissemination) is regulated by detailed job descriptions.

The employees of our company responsible for external contacts have sufficient resources for $\quad 0.84$

carrying out this activity.

Specific incentive schemes motivate employees to maintain relations with external contacts. $\quad 0.67$

We encourage all employees to be open to external input sources.

$(\alpha=0.88 ;$ AVE $=0.69)$

( 1 = strongly disagree, $5=$ strongly agree $)$

The project objectives, project progress, and the project decisions are known and accessible to all the 0.90 team members of a cooperation project.

The actual contributions of the cooperation partners are regularly compared with the agreed $\quad 0.75$ contributions.

The cooperation partners regularly come to agreements, e.g., in joint meetings, progress, and result 0.70 reports.

Employees who carry out cooperation activities know exactly which information may be passed on 0.85

to cooperation partners and which may not.

We regularly evaluate all cooperation activities.

0.92

\section{Appendix B}

\section{Service offerings}

- What service types does your firm develop?

- How strong is the relevance of service offerings in your organization?

2. Ecosystem configuration

- Who are the participants of your ecosystem? What is your role? What is the ultimate goal that unites all the players?

- Who brings resources, solves the problem, manages the process?

- What are the rules of the game? Where does the power lie?

- How does the money flow?

- Are there differences between regional, national, and international ecosystems?

3. Drivers and challenges

- What are the drivers for developing services in your ecosystem?

- Are there dependencies from other ecosystem actors?

- What are the key challenges for your firm in developing, configuring, and delivering advanced services within an ecosystem?

- Are all the challenges solved optimally? Are there cultural challenges?

- What is the challenge/need of the ultimate customer(s) of the ecosystem?

- What is your value-added share?

4. Dynamic capabilities

- Describe how you are dealing with these challenges and what activities are needed to be able to offer more advanced services within ecosystems?

- Is the complex solution that the ecosystem provides optimal? Which capabilities do you need to solve the ecosystem problem?

- Can you think of a better way to solve the problem?

- Could you provide a better solution to another part of the challenge that is currently served poorly? 
- Can you provide a better service to your part of the challenge?

\section{References}

Adner, R. (2017). Ecosystem as structure: An actionable construct for strategy. Journal of Management, 43(1), 39-58.

Adner, R., \& Kapoor, R. (2010). Value creation in innovation ecosystems: How the structure of technological interdependence affects firm performance in new technology generations. Strategic Management Journal, 31(3), 306-333.

Adner, R., \& Kapoor, R. (2016). Innovation ecosystems and the pace of substitution: Re-examining technology S-curves. Strategic Management Journal, 37(4), 625-648.

Akaka, M. A., Vargo, S. L., \& Lusch, R. F. (2013). The complexity of context: A service ecosystems approach for international marketing. Journal of Marketing Research, 21(4), 1-20.

Amabile, T. M., Conti, R., Coon, H., Lazenby, J., \& Herron, M. (1996). Assessing the work environment for creativity. Academy of Management Journal, 39(5), 1154-1184.

Atuahene-Gima, K., \& Evangelista, F. (2000). Cross-functional influence in new product development: An exploratory study of marketing and R\&D perspectives. Management Science, 46(10), 1269-1284.

Baines, T., \& Lightfoot, H. W. (2013). Servitization of the manufacturing firm: Exploring the operations practices and technologies that deliver advanced services. International Journal of Operations \& Production Management, 34(1), 2-35.

Baines, T. S., Lightfoot, H. W., Benedettini, O., \& Kay, J. M. (2009). The servitization of manufacturing: A review of literature and reflection on future challenges. Journal of Manufacturing Technology Management, 20(5), 547-567.

Barney, J. B. (1986). Organizational culture: Can it be a source of sustained competitive advantage? Academy of Management Review, 11(3), 656-665.

Benedettini, O., Swink, M., \& Neely, A. (2017). Examining the influence of service additions on manufacturing firms' bankruptcy likelihood. Industrial Marketing Management, 60, 112-125.

Beverland, M. B., \& Lindgreen, A. (2010). What makes a good case study? A positivist review of qualitative case research published in Industrial Marketing Management, 1971-2006. Industrial Marketing Management, 39(1), 56-63.

Blindenbach-Driessen, F., \& Van den Ende, J. (2014). The locus of innovation: The effect of a separate innovation unit on exploration, exploitation, and ambidexterity in manufacturing and service firms. Journal of Product Innovation Management, 31(5), 1089-1105.

Calantone, R. J., \& Vickery, S. K. (2010). Introduction to the special topic forum: Using archival and secondary data sources in supply chain management research. Journal of Supply Chain Management, 46(4), 3-11.

Chin, W. W. (1998). The partial least squares approach to structural equation modeling. Modern Methods for Business Research, 295(2), 295-336.

Cusumano, M. A., Kahl, S. J., \& Suarez, F. F. (2015). Services, industry evolution, and the competitive strategies of product firms. Strategic Management Journal, 36(4), $559-575$.

Den Hertog, P., Van der Aa, W., \& De Jong, M. W. (2010). Capabilities for managing service innovation: towards a conceptual framework. Journal of Service Management, 21(4), 490-514.

Dhanaraj, C., \& Parkhe, A. (2006). Orchestrating innovation networks. Academy of Management Review, 31(3), 659-669.

Eisenhardt, K. M. (1989). Building theories from case study research. The Academy of Management Review, 14(4), 19.

Eisenhardt, K. M., \& Martin, J. A. (2000). Dynamic capabilities: What are they? Strategic Management Journal, 1105-1121.

Eloranta, V., \& Turunen, T. (2015). Seeking competitive advantage with service infusion: A systematic literature review. Journal of Service Management, 26(3), 394-425.

Fang, E., Palmatier, R., \& Steenkamp, J. B. (2008). Effect of service transition strategies on firm value. Journal of Marketing, 72(1), 1-14.

Fischer, T., Gebauer, H., Gregory, M., Ren, G., \& Fleisch, E. (2010). Exploitation or exploration in service business development? Insights from a dynamic capabilities perspective. Journal of Service Management, 21(5), 591-624.

Ford, D., \& Gadde, L.-E. (2003). The manager and the relationship. In D. Ford, L.-E. Gadde, H. Håkansson, \& I. Snehota (Eds.). Managing business relationships. Chichester: John Wiley \& Sons.

Fornell, C., \& Larcker, D. F. (1981). Evaluating structural equation models with unobservable variables and measurement error. Journal of Marketing Research, 39-50.

Frow, P., McColl-Kennedy, J. R., \& Payne, A. (2016). Co-creation practices: Their role in shaping a health care ecosystem. Industrial Marketing Management, 56, 24-39.

Gadrey, J., Gallouj, F., \& Weinstein, O. (1995). New modes of innovation - how services benefit industry. International Journal of Service Industry Management, 6(3), 4-16.

Gallouj, F., \& Weinstein, O. (1997). Innovation in services. Research Policy, 26(4-5), 537-556.

Gebauer, H., Fischer, T., \& Fleisch, E. (2010). Exploring the interrelationship among patterns of service strategy changes and organizational design elements. Journal of Service Management, 21(1), 103-129.

Gebauer, H., Fleisch, E., \& Friedli, T. (2005). Overcoming the service paradox in manufacturing companies. European Management Journal, 23(1), 14-26.

Gulati, R., Puranam, P., \& Tushman, M. (2012). Meta-organization design: Rethinking design in interorganizational and community contexts. Strategic Management Journal, 33(6), 571-586.

Hair, J. F., Black, W. C., Babin, B. J., \& Anderson, R. E. (2009). Multivariate Data Analysis.

Helfat, C. E., \& Campo-Rembado, M. A. (2015). Integrative capabilities, vertical integration, and innovation over successive technology lifecycles. Organization Science,
27(2), 249-264.

Helms, T. (2016). Asset transformation and the challenges to servitize a utility business model. Energy Policy, 91, 98-112.

Hienerth, C., Lettl, C., \& Keinz, P. (2014). Synergies among producer firms, lead users, and user communities: The case of the LEGO producer-user ecosystem. Journal of Product Innovation Management, 31(4), 848-866.

Hill, C. W. L., \& Rothaermel, F. T. (2003). The performance of incumbent firms in the face of radical technological innovation. Acad. Management Rev. 28, 257-274.

Homburg, C., Fassnacht, M., \& Günther, C. (2003). The role of soft factors in implementing a service-oriented strategy in industrial marketing companies. Journal of Business-to Business Marketing, 10(2), 23-51.

Huikkolla, T., \& Kohtamäki, M. (2017). Solution providers' strategic capabilities. Journal of Business \& Industrial Marketing, 32(5), 752-777.

Huikkolla, T., Ylimäki, J., \& Kohtamäki, M. (2013). Joint learning in R\&D collaborations and the facilitating relational practices. Industrial Marketing Management, 42(7), 1167-1180.

Huikkola, T., Kohtamäki, M., \& Rabetino, R. (2016). Resource realignment in servitization: A study of successful service providers explores how manufacturers modify their resource bases in transitioning to service-oriented offerings. Research-Technology Management, 59(4), 30-39.

Iansiti, M., \& Levien, R. (2004). The keystone advantage: What the new dynamics of business ecosystems mean for strategy, innovation, and sustainability. Harvard Business Press.

Jacobides, M. G., Cennamo, C., \& Gawer, A. (2018). Towards a theory of ecosystems. Strategic Management Journal, 39(8), 2255-2276.

Kindström, D., \& Kowalkowski, C. (2014). Service innovation in product-centric firms: A multidimensional business model perspective. Journal of Business \& Industrial Marketing, 29(2), 96-111.

Kindström, D., Kowalkowski, C., \& Sandberg, E. (2013). Enabling service innovation: A dynamic capabilities approach. Journal of Business Research, 66(8), 1063-1073.

Kindström, D., \& Ottosson, M. (2016). Local and regional energy companies offering energy services: Key activities and implications for the business model. Applied Energy, 171, 491-500.

Kohtamäki, M., \& Partanen, J. (2016). Co-creating value from knowledge-intensive business services in manufacturing firms: The moderating role of relationship learning in supplier-customer interactions. Journal of Business Research, 69(7), 2498-2506.

Kohtamäki, Marko, \& Rajala, Risto (2016). Theory and practice of value co-creation in B2B systems.

Kohtamäki, M., Partanen, J., Parida, V., \& Wincent, J. (2013). Non-linear relationship between industrial service offering and sales growth: The moderating role of network capabilities. Industrial Marketing Management, 42(8), 1374-1385.

Kowalkowski, C., Gebauer, H., Kamp, B., \& Parry, G. (2017). Servitization and deservitization: Overview, concepts, and definitions. Industrial Marketing Management, 60, 4-10.

Kowalkowski, C., Gebauer, H., \& Oliva, R. (2017). Service growth in product firms: Past, present, and future. Industrial Marketing Management, 60, 82-88.

Kowalkowski, C., Windahl, C., Kindström, D., \& Gebauer, H. (2015). What service transition? Rethinking established assumptions about manufacturers' service-led growth strategies. Industrial Marketing Management, 45, 59-69.

Kroh, J., Lütjen, H., Globocnik, D., \& Schultz, C. (2018). Use and efficacy of information Technology in Innovation Processes: The specific role of Servitization. Journal of Product Innovation Management, 35, 720-741.

Lawson, B., \& Samson, D. (2001). Developing innovation capability in organizations: A dynamic capabilities approach. International Journal of Innovation Management, 5(3), 377-400.

Lightfoot, H., Baines, T., \& Smart, P. (2013). The servitization of manufacturing: A systematic literature review of interdependent trends. International Journal of Operations \& Production Management, 33(11/12), 1408-1434.

Lusch, R. F., \& Vargo, S. L. (2014). Service-dominant logic: Premises, perspectives, possibilities. Cambridge University Press.

Lütjen, H., Tietze, F., \& Schultz, C. (2017). Service transitions of product-centric firms: An explorative study of service transition stages and barriers in Germany's energy market. International Journal of Production Economics, 192, 106-119.

Martinez, V., Neely, A., Velu, C., Leinster-Evans, S., \& Bisessar, D. (2017). Exploring the journey to services. International Journal of Production Economics, 192, 66-80.

McGraw, K. O., \& Wong, S. P. (1996). Forming inferences about some intraclass correlation coefficients. Psychological Methods, 1(1), 30.

Mele, C., Pels, J., \& Storbacka, K. (2015). A holistic market conceptualization. Journal of the Academy of Marketing Science, 43(1), 100-114.

Miles, M. B., \& Huberman, A. M. (1994). Qualitative data analysis: An expanded sourcebook. Thousand Oaks: Sage Publications Ltd.

Neely, A. (2008). Exploring the financial consequences of the servitization of manufacturing. Operations Management Research, 1(2), 103-118.

Nijssen, E. J., Hillebrand, B., Vermeulen, P. A., \& Kemp, R. G. (2006). Exploring product and service innovation similarities and differences. International Journal of Research in Marketing, 23(3), 241-251.

Opresnik, D., \& Taisch, M. (2015). The value of big data in servitization. International Journal of Production Economics, 165, 174-184.

Page, A. L., \& Schirr, G. R. (2008). Growth and development of a body of knowledge: 16 years of new product development research, 1989-2004. Journal of Product Innovation Management, 25(3), 233-248.

Paiola, M., Saccani, N., Perona, M., \& Gebauer, H. (2013). Moving from products to 
solutions: Strategic approaches for developing capabilities. European Management Journal, 31, 390-409.

Parida, V., Sjödin, D. R., Wincent, J., \& Kohtamäki, M. (2014). Mastering the transition to product-service provision: Insights into business models, learning activities, and capabilities. Research-Technology Management, 57(3), 44-52.

Raddats, C., Burton, J., \& Ashman, R. (2015). Resource configurations for services success in manufacturing companies. Journal of Service Management, 26(1), 97-116.

Ritter, T., \& Gemünden, H. G. (2003). Network competence: Its impact on innovation success and its antecedents. Journal of Business Research, 56(9), 745-755.

Ritter, T., Wilkinson, I. F., \& Johnston, W. J. (2004). Managing in complex business networks. Industrial Marketing Management, 33(3), 175-183.

Roland Berger (2014). Escaping the commodity trap - How to regain a competitive edge in commodity markets. April 2014.

Schultz, C., Globocnik, D., Kock, A., \& Salomo, S. (2018). Application and performance impact of stage-gate systems: The role of services in the firm's business focus. $R \& D$ Management, in printhttps://doi.org/10.1111/radm.12341.

Schultz, C., Salomo, S., \& Talke, K. (2013). Measuring new product portfolio innovativeness: How differences in scale width and evaluator perspectives affect its relationship with performance. Journal of Product Innovation Management, 30(Supplement S1), 93-109.

Sjödin, D. R., Parida, V., \& Wincent, J. (2016). Value co-creation process of integrated product-services: Effect of role ambiguities and relational coping strategies. Industrial Marketing Management, 56, 108-119.

Spring, M., \& Araujo, L. (2013). Beyond the service factory: Service innovation in manufacturing supply networks. Industrial Marketing Management, 42(1), 59-70.

Storey, C., Cankurtaran, P., Papastathopoulou, P., \& Hultink, E. J. (2016). Success factors for service innovation: A meta-analysis. Journal of Product Innovation Management, $33(5), 527-548$

Story, V. M., Raddats, C., Burton, J., Zolkiewski, J., \& Baines, T. (2017). Capabilities for advanced services: A multi-actor perspective. Industrial Marketing Management, 60, 54-68.

Teece, D. J. (2007). Explicating dynamic capabilities: The nature and microfoundations of (sustainable) enterprise performance. Strategic Management Journal, 28(13), 1319-1350.
Teece, D. J. (2016). Profiting from innovation in the digital economy: Standards, com plementary assets, and business models in the wireless world.

Teece, D. J., Pisano, G., \& Shuen, A. (1997). Dynamic capabilities and strategic management. Strategic Management Journal, 18(7), 509-533.

Tietze, F., Schiederig, T., \& Herstatt, C. (2013). Firms' transition to green product service system innovators: Cases from the mobility sector. International Journal of Technology Management, 63(1/2), 51-69.

Töytäri, P., Turunen, T., Klein, M., Eloranta, V., Biehl, S., \& Rajala, R. (2018). Aligning the mindset and capabilities within a business network for successful adoption of Smart services. Journal of Product Innovation Management, 35(5), 763-779.

Tsujimoto, M., Kajikawa, Y., Tomita, J., \& Matsumoto, Y. (2018). A review of the ecosystem concept-Towards coherent ecosystem design. Technological Forecasting and Social Change, 136, 49-58.

Vargo, S. L., \& Lusch, R. F. (2011). It's all B2B... and beyond: Toward a systems perspective of the market. Industrial marketing management, 40(2), 181-187.

Walter, A., Auer, M., \& Ritter, T. (2006). The impact of network capabilities and entrepreneurial orientation on university spin-off performance. Journal of Business Venturing, 21(4), 541-567.

Wang, C. L., \& Ahmed, P. K. (2007). Dynamic capabilities: A review and research agenda. International Journal of Management Reviews, 9(1), 31-51.

Wieland, H., Polese, F., Vargo, S. L., \& Lusch, R. F. (2012). Toward a service (eco)systems perspective on value creation. International Journal of Service Science, Management, Engineering and Technology, 3(3), 12-24.

Windahl, C., \& Lakemond, N. (2010). Integrated solutions from a service-centered perspective: Applicability and limitations in the capital goods industry. Industrial Marketing Management, 39(8), 1278-1290.

Yin, R. K. (2009). Case study research: Design and methods. Applied social research methods series. Thousand Oaks: Sage Publications.

ZEW (Zentrum für Europäische Wirtschaftsforschung GmbH) (2015). Innovationsverhalten der deutschen Wirtschaft. [Online] Available at: http://ftp.zew.de/pub/zew-docs/ mip/14/mip_2014.pdf. (accessed 11.06.19.).

Zimmermann, A., Raisch, S., \& Birkinshaw, J. (2015). How is ambidexterity initiated? The emergent charter definition process. Organization Science, 26(4), 1119-1139. 